\title{
Hand hygiene compliance of healthcare professionals in an emergency department*
}

\author{
Adesão dos profissionais de saúde à higienização das mãos em pronto-socorro \\ Adhesión de los profesionales sanitarios a la higienización \\ de las manos en servicio de urgencias
}

Caroline Zottele ${ }^{1}$, Tania Solange Bosi de Souza Magnago ${ }^{2}$, Angela Isabel dos Santos Dullius ${ }^{3}$, Adriane Cristina Bernat Kolankiewicz ${ }^{4}$, Juliana Dal Ongaro ${ }^{2}$

How to cite this article:

Zottele C, Magnago TSBS, Dullius AIS, Kolankiewicz ACB, Ongaro JD. Hand hygiene compliance of healthcare professionals in an emergency department. Rev Esc Enferm USP. 2017;51:e03242. DOI: http://dx.doi.org/10.1590/S1980-220X2016035503242

\footnotetext{
* Extracted from the dissertation "Higienização das mãos: conhecimento e adesão de profissionais da saúde em unidade de pronto-socorro", Programa de Pós-Graduação em Enfermagem, Universidade Federal de Santa Maria, 2016.

${ }^{1}$ Universidade Federal de Santa Maria, Hospital Universitário de Santa Maria, Santa Maria, RS, Brazil.

${ }^{2}$ Universidade Federal de Santa Maria, Departamento de Enfermagem, Santa Maria, RS, Brazil.

${ }^{3}$ Universidade Federal de Santa Maria, Departamento de Estatística, Santa Maria, RS, Brazil.

${ }^{4}$ Universidade Regional do Noroeste do Estado do Rio Grande do Sul, Departamento de Ciências da Vida, Ijuí, RS, Brazil.
}

\section{ABSTRACT}

Objective: To analyze compliance with hand hygiene by healthcare professionals in an emergency department unit. Method: This is a longitudinal quantitative study developed in 2015 with healthcare professionals from a university hospital in the state of Rio Grande do Sul. Each professional was monitored three times by direct non-participant observation at WHO's five recommended moments in hand hygiene, taking the concepts of opportunity, indication and action into account. Descriptive and analytical statistics were used. Results: Fifty-nine healthcare professionals participated in the study. The compliance rate was $54.2 \%$. Nurses and physiotherapists showed a compliance rate of $66.6 \%$ and resident physicians, $41.3 \%$. When compliance was compared among professional categories, nurses showed greater compliance than resident physicians (OR=2.83, CI=95\%:1.09-7.34). Conclusion: Hand hygiene compliance was low. Multidisciplinary approaches could be important strategies for forming partnerships to develop learning and implementation of hand hygiene practices.

\section{DESCRIPTORS}

Hand Hygiene; Patient Safety; Cross Infection; Emergency Nursing; Advance Directive Adherence; Emergency Medical Services. 


\section{INTRODUCTION}

Healthcare-related infections (HCRI) are adverse events that occur in healthcare services worldwide, even when broadly avoidable ${ }^{(1)}$. A study of the prevalence of HCRI, coordinated by the World Health Organization (WHO) in 55 hospitals in 14 countries in Asia, Europe, the Eastern Mediterranean and the Western Pacific revealed that on average $8.7 \%$ of patients experience infections during hospitalization $^{(2)}$. In developed countries, HCRI rates ranged from $5 \%$ to $15 \%$ in hospitalized patients, and may have affected from $9 \%$ to $37 \%$ of patients admitted to intensive care units (ICUs) ${ }^{(2)}$.

In 2004, the World Alliance for Patient Safety launched their First Global Challenge, with a central focus on HCRI prevention. In Brazil, the challenge was entitled "Clean Care is Safer Care." It was implemented in the biennium 20052006, aiming at promoting hand hygiene as a sensitive and effective method to prevent infections ${ }^{(2)}$. Even 10 years later, the proposal focused on patient safety, which points to hand hygiene as a simple and effective measure in the prevention of HCRI still has an impact on current clinical and care practices in different services ${ }^{(3)}$.

Although scientific evidence points to a relationship between an increase in hand hygiene and reduction of HCRI rates, consistency and compliance rates remain low ${ }^{(4-5)}$. There are efforts to increase this practice; however, the general rate of hand hygiene compliance has been around $40 \%$, varying from $5 \%$ to $81 \%{ }^{(6)}$. Scientific evidence has shown a compliance rate of $20 \%$ by ICU healthcare professionals (nurses, physicians and physiotherapists) $)^{(7-8)}, 29 \%$ in emergency rooms ${ }^{(9)}$, and $40 \%$ among medical students in open units ${ }^{(10)}$, confirming the low consistency rates.

Intensive care units are among the most investigated sites for checking hand hygiene compliance rates. However, the development of studies in other healthcare settings that are as complex and dynamic as ICUs is very important. Emergency room units can be considered as critical scenarios for hand hygiene compliance because of a combination of factors, such as overcrowding, heavy workloads, lack of time and, often, staff shortages ${ }^{(1)}$. These conditions, along with the complexity and unpredictability of patients, stress in the professional team, and resource/infrastructure constraints, compromise patient safety and lead to adverse events. Among those events are healthcare-related infections due to low compliance with hand hygiene.

In a review study on HCRI control in emergency room units which included 22 publications, the rates of hand hygiene compliance ranged from $7.7 \%$ to $89.7 \%{ }^{(1)}$. The researchers concluded that it is not possible to draw conclusions about these rates, given the variety of methods of observation used. In 2007, WHO published "Five Moments for Hand Hygiene" ${ }^{(11)}$, which can provide an important framework for comparing evidence at the global level.

The research question for the present study was: What is the rate of compliance with hand hygiene practiced by healthcare professionals working in the emergency room at the five moments for hand hygiene recommended by WHO? To answer this question, we aimed to analyze the hand hygiene compliance of healthcare professionals in an emergency room.

\section{METHOD}

This was a quantitative study with a longitudinal design, developed in an emergency department for adult patients at a university hospital in the central region of the state of Rio Grande do Sul, Brazil. The unit has 22 beds to accommodate patients until transfer to inpatient units. In 2015, this facility presented an occupancy rate of $180.6 \%$, with an average of 43 patients/day and average stay of 4.7 days. Excess patients were accommodated on stretchers in the corridors of the department.

The unit's physical structure is divided into: observation room 1 (11 beds), observation room 2 (eight beds), three bedrooms with anterooms, two nursing stations, two medical offices, an administrative office, an emergency room, a medication preparation room, a supply room, and a stockroom. The name "observation room" was created because the emergency department is not an inpatient unit. However, because of lack of beds in the wards, the patients end up staying in the emergency room longer (4.7 days, as previously stated).

In both room 1 and room 2, the patients are already hospitalized and are waiting for the release of beds in the hospitalization units. The difference is that patients with a stabilized clinical picture requiring routine procedures (medication, dressings, vital sign check, etc.) are allocated to observation room 1; those whose clinical picture is still considered unstable, who are on mechanical ventilation and vasoactive drugs, among others, who may require maneuvers or urgency/emergency procedures (CPR, for example) are accommodated in the beds of observation room 2 . This allocation dynamic is important for both patient safety and rapid intervention by professionals. The team of physicians, residents and physiotherapists is the same for both rooms. The nursing team is divided into one team for each room.

As for the physical structure and resources specifically required for hand hygiene, observation room 1 has five sinks, four liquid soap dispensers, four paper towel dispensers, and eight alcohol-gel dispensers. It is worth noting that there is one liquid soap and paper towel dispenser available for every two sinks. Observation room 2 has one sink and a liquid soap dispenser, and another dispenser for alcohol gel. None of the rooms have alcohol gel dispensers by the bedside, but they are fixed on the tables for procedures that are used by the healthcare professionals.

The population consisted of 81 health professionals: 21 nurses, 42 nursing technicians, 2 physiotherapists, and 16 resident physicians, distributed in the different work shifts. The inclusion criteria were as follows: to be working in the emergency department and, at the time of observation, to be providing assistance to patients who were already stabilized, that is, those who were clinically stable and awaiting beds in the admission units. Professionals were excluded if they were on leave for health treatment, or on leave for any other reason during the period of data collection.

Of the total estimated population ( $\mathrm{N}=81), 12(14.8 \%)$ participants were excluded from the study for reasons related to a leave for health treatment. Thus, the eligible population was 69 professionals. They were listed and contacted individually during their work shifts, and invited to participate in the study. Agreement was obtained by 59 (85.5\%) health 
professionals (28 nursing technicians, 17 nurses, 12 resident physicians and 2 physiotherapists). Losses (14.5\%) resulted from refusal to participate $(\mathrm{N}=2)$ and non-follow-up in the three follow-ups $(\mathrm{N}=8)$.

Data collection took place from March to July 2015, using the instrument called the Observation Formulary ${ }^{(11-12)}$, and was performed by a single trained and registered nurse, called the observer. Professional training included reading of the Observers Manual ${ }^{(11-12)}$ and a workshop on drug preparation and administration in a nursing techniques laboratory. The activity developed in the laboratory was an important time for the observer to practice completion of the observation form while accompanying a professional during the performance of all the actions involved in the procedure. The exercise was repeated until there was no doubt about the observer's answers. This control was aimed at avoiding evaluation bias. Seven sessions of pilot observations were also carried out in the emergency room to introduce the observer, provide familiarity with the environment, and minimize the Hawthorne $^{(13)}$ effect. This effect, initially documented during productivity studies at Hawthorne Electric Plant (US) in the 1930s, refers to behavioral changes of professionals when observed. The researchers noted that, regardless of the variable being studied, work performance improved when workers were being observed ${ }^{(13)}$.

The pilot observations were not included in the study. The observation of the professionals was direct, systematized and non-participant during the development of activities, seeking to visualize the practice of hand hygiene in the five moments recommended by WHO. To accomplish this, the essential concepts of Indication, Action and Opportunity were assumed ${ }^{(11-12)}$. Each observation was understood as a monitoring session, with a start time and end time; the predetermined maximum time was 20 minutes, which varied according to the routines observed ${ }^{(11-12)}$. The observations took place between March 12 and July 1, 2015, during different periods of the month and the week, and during the three work shifts (morning, afternoon and night). Three data collection sessions were carried out with each research participant, and an opportunity for hand hygiene was observed in each session, considering the time available for the research.

The observations took place only in observation room 1 , because the patients there are clinically stabilized (awaiting a bed in the admission units), and the professionals can develop the activities with greater tranquility. Observations of compliance with hand hygiene were avoided during the care of patients in clinical or surgical emergencies with whom, due to imminent risk of death, the professionals could choose to perform procedures at the expense of hand hygiene in the recommended five moments (a situation that could have information bias). In addition, to avoid bias in the flow of data collection, considering the turnover of professionals in the daily work schedules, it was decided that a worksheet with the schedules of the participants would be used.

Microsoft Excel ${ }^{\circledR}$ (version 2010) was used to organize the data, with double independent information entry. After checking for errors and inconsistencies, BioEstat $5.0^{\circledR}$ software was used to analyze the data.

The following formula was used to calculate hand hygiene compliance: number of hand hygiene actions performed by health professionals/number of opportunities for hand hygiene, multiplied by 100 . Qualitative variables were analyzed using absolute (N) and relative (\%) frequencies. Quantitative variables were evaluated through descriptive statistics, using means and standard deviation (SD), because the data had a normal distribution. To compare the proportions of compliance among the professional categories, binomial tests were performed, and odds ratios and their confidence intervals ( $95 \% \mathrm{CI})$ were calculated. The level of significance considered in all analyses was $5 \%$.

The research was approved by a research ethics committee, on January 17,2015, report number: 934.215. The professionals were given information about the research objectives and strategy for data collection (observation) and the anonymity of data, and asked about their willingness to participate. Those who agreed to participate signed two copies of the Free and Informed Consent Form (Resolution 466/2012).

\section{RESULTS}

\section{HAND HYGIENE PRACTICE CHARACTERIZATION}

The 59 health professionals were followed during three observation sessions. At each session, an opportunity for hand hygiene was observed, i.e., daily work routines involving procedures performed by healthcare professionals such as: peripheral and central venous puncture, intermittent urinary catheter, intubation and tracheal aspiration, vital sign check, and administration of intravenous drugs. In total, 166 sessions were performed, so 166 opportunities (100\%) for hand hygiene were observed.

Observations occurred between March 12, 2015 and July 1, 2015, totaling 111 days of monitoring. The mean time interval between the first and last follow-up sessions was 28 days ( $\mathrm{SD}=9$ days). Between first and second sessions, the mean interval was 14 days ( $\mathrm{SD}=10$ days). The observation sessions lasted on average 11 minutes $(\mathrm{SD}=50 \mathrm{~s})$ and occurred in all three work shifts: $77(46 \%)$ in the morning shift; 32 (20\%) in the afternoon shift; and 57 (34\%) in the night shift. Table 1 shows a description of the indications observed in each monitoring session.

Table 1 - Description of total indications for hand hygiene - Santa Maria, Rio Grande do Sul, Brazil, 2015.

\begin{tabular}{|c|c|c|c|c|c|c|c|c|c|c|c|c|}
\hline \multicolumn{13}{|c|}{ Opportunities for Hand Hygiene } \\
\hline \multirow{3}{*}{$\begin{array}{l}\text { Monitoring } \\
\text { Sessions }\end{array}$} & \multicolumn{10}{|c|}{ Indications* } & \multirow{2}{*}{\multicolumn{2}{|c|}{ Total }} \\
\hline & \multicolumn{2}{|c|}{ Before contact } & \multicolumn{2}{|c|}{ Before Proced. } & \multicolumn{2}{|c|}{ After Fluids } & \multicolumn{2}{|c|}{ After Contact } & \multicolumn{2}{|c|}{ After Superf. } & & \\
\hline & $\mathbf{N}$ & $\%$ & $\mathbf{N}$ & $\%$ & $\mathbf{N}$ & $\%$ & $\mathbf{N}$ & $\%$ & $\mathbf{N}$ & $\%$ & $\mathbf{N}$ & $\%$ \\
\hline Session 1 & 14 & 23.7 & 3 & 5.1 & 12 & 20.3 & 14 & 23.7 & 16 & 27.1 & 59 & 35.5 \\
\hline
\end{tabular}




\begin{tabular}{|c|c|c|c|c|c|c|c|c|c|c|c|c|}
\hline \multirow{4}{*}{$\begin{array}{c}\text { Monitoring } \\
\text { Sessions }\end{array}$} & \multicolumn{10}{|c|}{ Opportunities for Hand Hygiene } & \multirow{3}{*}{\multicolumn{2}{|c|}{ Total }} \\
\hline & & & & & Indi & tions* & & & & & & \\
\hline & \multicolumn{2}{|c|}{ Before contact } & \multicolumn{2}{|c|}{ Before Proced. } & \multicolumn{2}{|c|}{ After Fluids } & \multicolumn{2}{|c|}{ After Contact } & \multicolumn{2}{|c|}{ After Superf. } & & \\
\hline & $\mathbf{N}$ & $\%$ & $\mathbf{N}$ & $\%$ & $\mathbf{N}$ & $\%$ & $\mathbf{N}$ & $\%$ & $\mathbf{N}$ & $\%$ & $\mathbf{N}$ & $\%$ \\
\hline Session 2 & 10 & 18.2 & 5 & 9.1 & 12 & 21.8 & 14 & 25.5 & 14 & 25.5 & 55 & 33.1 \\
\hline Session 3 & 9 & 17.3 & 5 & 9.6 & 11 & 21.2 & 17 & 32.7 & 10 & 19.2 & 52 & 31.3 \\
\hline Total & 33 & 19.8 & 13 & 7.8 & 35 & 21.0 & 45 & 27.0 & 40 & 24.9 & 166 & 100 \\
\hline
\end{tabular}

*Notes: Before Contact: before contact with the patient; Before the Proced.: before the performance of aseptic procedure; After Fluids: after risk of exposure to body fluids; After Contact: after contact with the patient; After Superf.: after contact with areas near the patient; $(\mathrm{N}=166)$.

\section{A) FIRST MONITORING SESSION}

In the first monitoring session for health professionals, 59 (35.5\%) opportunities for hand hygiene were observed, with a mean duration of $10 \mathrm{~min} 20 \mathrm{~s}(\mathrm{SD}=4 \mathrm{~min} 52 \mathrm{~s})$ per session. Hand hygiene was observed for 30 (51\%) opportunities, of which 23 (77\%) were performed with soap and water and seven (23\%) with alcohol solution.

\section{B) Second monitoring Session}

In the second session, 55 (33\%) opportunities for hand hygiene were observed, with a mean duration of 11 min 50s ( $\mathrm{SD}=5$ min $21 \mathrm{~s})$ per session. Hand hygiene was observed for 29 (53\%) opportunities, of which 24 (83\%) were performed with water and soap and five (17\%) with alcohol solution.

\section{C) THIRD MONITORING SESSION}

Regarding the third and final session, 52 (31\%) opportunities were observed, with an average duration of $10 \mathrm{~min} 40 \mathrm{~s}$ ( $\mathrm{SD}=4 \mathrm{~min} 38 \mathrm{~s}$ ) per session. Hand hygiene was observed for 31 (59.6\%) opportunities, 27 (87\%) of which were performed with soap and water and four (13\%) with alcoholic solution.

\section{COMPLIANCE TO HAND HYGIENE}

The general compliance with hand hygiene by the emergency department health professionals was $54.2 \%$, being higher in the last session (59.6\%) (Table 2).

Table 2 - Number of opportunities observed, number of hand hygiene actions performed and hand hygiene compliance rate - Santa Maria, Rio Grande do Sul, Brazil, 2015.

\begin{tabular}{cccr}
\hline Monitoring Session & No. of Opportunities Observed & HH Performed & Compliance Rate (\%) \\
\hline Session 1 & 59 & 30 & 50.8 \\
Session 2 & 55 & 29 & 52.7 \\
Session 3 & 52 & 31 & 59.6 \\
\hline Total & $\mathbf{1 6 6}$ & $\mathbf{9 0}$ & $\mathbf{5 4 . 2}$ \\
\hline
\end{tabular}

According to each monitoring session and professional category, the compliance rate for the first session for the nurses was $64.7 \%$, for the nursing technicians, $50 \%$, for the physiotherapists, $100 \%$, and for the resident physicians, $25 \%$. In the second session, the compliance rate for nurses was $62.5 \%$, for nursing technicians, $46.4 \%$, for physiotherapists, $50 \%$, and for resident physicians, $55.6 \%$. In the final session, the compliance rate for nurses was $73.3 \%$, for nursing technicians, $55.5 \%$, for physiotherapists and resident physicians, $50 \%$ each.

At the time of data collection, no training on the theme was carried out by the researcher or the institution. Thus, the apparent increase in the compliance rate from the first $(50.8 \%)$ to the last monitoring session (59.6\%) may have occurred due to the fact that the observations were performed directly, so the professionals may have changed their behaviors and attitudes because they were being observed (the Hawthorne effect). This increase was not statistically significant $(\mathrm{p}=0.3542)$.

When the compliance rate with hand hygiene by category was checked, nurses and physiotherapists showed the highest rate $(66.6 \%)$, followed by nursing technicians (50.6\%) and resident physicians (41.3\%) (Table 3).

Table 3 - Number of opportunities observed and number of actions undertaken per professional category and rate of compliance with hand hygiene - Santa Maria, Rio Grande do Sul, Brazil, 2015.

\begin{tabular}{cccc}
\hline \multirow{2}{*}{ Professional category } & \multicolumn{2}{c}{ Compliance per professional category } \\
\cline { 2 - 4 } & No. of Opportunities Observed & HH Performed & Compliance Rate (\%) \\
\hline Nurses & 48 & 32 & 66.6 \\
Nursing Technicians & 83 & 42 & 50.6 \\
Physiotherapists & 6 & 4 & 66.6 \\
Resident Physicians & 29 & 12 & 41.3 \\
\hline Total & $\mathbf{1 6 6}$ & $\mathbf{9 0}$ & 54.2 \\
\hline
\end{tabular}


When comparing compliance among the categories of professionals (two to two) through the binomial test, taking the category of nurses as the reference for comparison, it was found that nurses were more compliant with hand hygiene than resident physicians $(\mathrm{p}=0.03)$. The results for calculation of the effect measure were significant at the $5 \%$ level in the comparison of the category of nurses with the category of resident physicians (OR=2.83; CI: 95\% [1.09 - 7.34]). That is, the nurses presented 2.83 times more probability of compliance with hand hygiene when compared to the resident physicians.

\section{DISCUSSION}

\section{HAND HYGIENE PRACTICE CHARACTERIZATION}

In the present study, 59 health professionals were followed during three observation sessions. There were 166 opportunities for hand hygiene during 111 days of monitoring, with an average duration of $11 \mathrm{~min}$ ( $\mathrm{SD}=50$ seconds) per session. A Colombian study evaluated 180 opportunities with 26 health professionals ${ }^{(14)}$. In a reference hospital survey in Mali in Africa, the monitoring sessions had a mean duration of $16 \mathrm{~min}$ (ranging from 1 to $51 \mathrm{~min})^{(5)}$. Most of the sessions occurred in the day shift (66\%), similar to the Colombian study $(55 \%)^{(8)}$. The shifts and times monitored may be related to the inclusion criteria and the turnover of health professionals in daily work schedules in emergency rooms.

In the characterization of hand hygiene practice observed in the adult emergency room, the highest percentage of indications was observed in the first monitoring session (35.5\%). Indications after contact with the patient were observed in $27 \%$ of the sessions, followed by indications after contact with areas that are close to the patient, observed in $24.9 \%$ of the sessions. These results are in line with studies in ICUs ${ }^{(14-16)}$ that have carried out most observations of indications after contact with the patient, followed by contact with areas that are close to the patient, and then followed by contact with the patient and near areas. This evidence indicates that healthcare professionals in both emergency rooms and ICUs may be concerned about the risk of disease acquisition after the performance of procedures, and exposure to bodily fluids and potentially contaminated areas. There seems to be a banalization of the importance of offering safe care to patients by performing hand hygiene at all the times recommended by WHO.

At the same time, a minority of the indications observed $(7.8 \%)$ referred to the moment before an aseptic procedure. An even lower result was evidenced (5.4\%) in a hospital in the South of Brazil, pointing to the use of gloves as an important barrier that may interfere with hand hygiene compliance before this moment ${ }^{(16)}$. This is due to the fact that the professional can replace the use of gloves by hand hygiene, relating the act of hand hygiene only to self-protection and self-care ${ }^{(15-16)}$, setting aside the dissemination of microorganisms, and patient protection and safety. It should be noted that in the researched emergency room, the alcohol gel dispenser is fixed to the procedure table. This measure facilitates the performance of hand hygiene procedures; however, some professionals do not use it.

Hand hygiene with alcohol friction was observed for $16(9 \%)$ opportunities, unlike hand hygiene with water and soap, which was observed for 74 (45\%) opportunities. These results point to lack of knowledge about and lack of routine for rubbing the hands with alcohol preparations. From this perspective, it can be stated that habit and personal belief may exert a greater influence on compliance than knowledge of precautions and control measures for $\mathrm{HCRI}^{(17)}$. Another important point to be addressed is related to the national recommendations on the use of alcohol preparations for hand hygiene published by the National Health Surveillance Agency (Agência Nacional de Vigilância Sanitária - ANVISA). According to the Resolution of the Collegiate Board of Directors (RDC) no. $42^{(18)}$, the use of alcohol preparations in hand hygiene is mandatory in health services, regardless of the level of complexity of the service, provided there is evidence of antimicrobial efficacy by in vitro or in vivo tests ${ }^{(19)}$.

The advantages of alcohol preparations in relation to other products for hand hygiene are described and proven in the scientific literature. It is noted that the challenge involves the incorporation and acceptability of these products ${ }^{(20-21)}$ in daily care practices. There are many variables and institutional challenges involving the use of alcohol preparations. The direct variables are related to the compulsory use of alcohol preparations in health services and to the existence of some gaps in official regulations in this regard. The indirect variables refer to the effectiveness of the procedure, its duration, the volume of the product to be applied, and the indications for hand hygiene ${ }^{(19)}$.

\section{HAND HYGIENE COMPLIANCE}

In the adult emergency room, there was a low overall hand hygiene compliance rate (54.2\%). Research has shown variations in the compliance rates with hand hygiene reported by healthcare professionals, with percentages ranging from $8 \%$ to $84.5 \% \%^{(5,7-9,16,22-24)}$. However, different factors may be related to low compliance ${ }^{(4,25)}$. Among them, the following are highlighted: healthcare services with limited resources; overcrowding, with inadequate or no spatial separation between beds ${ }^{(26)}$; physical structure, which includes poorly located sinks ${ }^{(3,22)}$; the use of gloves ${ }^{(16)}$; ability, attitudes, and motivation ${ }^{(25)}$; the importance given by healthcare professionals to the risks of not being in compliance with the recommendations for hand hygiene; and the training received and the time provided for it ${ }^{(27)}$. Researchers also continue to point to factors related to inadequate flow of patient care due to overcrowding, heavy workloads, stress, activities with high risk of cross-transmission of pathogens, lack of knowledge about protocols for hand hygiene, lack of positive examples by their superiors, bad habits, simple forgetfulness, and skin irritation and drying caused by the successive use of products ${ }^{(1,4,9,15,20)}$.

In the present study, nurses and physiotherapists showed the highest percentage of compliance $(66.6 \%)$, and resident physicians, the lowest (41.4\%). Other studies have also 
identified higher rates of compliance among physiotherapists $(53.5 \% \text { and } 76.2 \%)^{(7,16)}$. In contrast to these results, a Colombian study and a Brazilian study reported low hand hygiene compliance among physiotherapists (5\% and 19.4\%, respectively $)^{(8,22)}$. In the present study, the calculation of the compliance rate by physiotherapists may have been influenced by the small number of professionals of this category who work in the unit $(\mathrm{N}=2)$. In addition, two other studies performed in ICUs have reported low compliance with hand hygiene among nurses $(25 \%, 22.7 \%)$ and resident physicians $(20.8 \%, 25.2 \%)^{(8.15)}$. Regarding the professional category of nursing technicians, one study identified lower compliance than that in this study $(29.8 \% \text { vs. } 50.6 \% \text {, respectively })^{(16)}$. The importance of hand hygiene for nursing technicians is highlighted, because they are the professionals who have more direct contact with the patient, 24 hours a day ${ }^{(16)}$.

Comparison of compliance among the professional categories of the adult emergency confirmed that nurses showed higher hand hygiene compliance than resident physicians. A study carried out in the emergency room of the New York University Medical Center evaluated the impact of alcohol gel dispensers on hand hygiene compliance, and identified a variation of $51 \%$ to $62 \%$ in the rate, but with no statistical difference between the professional categories $(p=0.1)^{(21)}$. In an ICU in Colombia, there was greater compliance among physicians than among nurses (25.2\% vs. $22.7 \%$, p>0.05), and greater compliance among physicians than among physiotherapists $(25.2 \% \text { vs. } 14.2 \% \%, p=0.004)^{(8)}$.

One study found a significant and opposite result to the one observed here ${ }^{(7)}$. Residents showed 3.12 times more probability of hand hygiene (95\% CI=1.04-9.38) when compared to ICU nurses. The authors concluded that it is necessary to use actions with a multimodal approach to improve hand hygiene compliance ${ }^{(7)}$.

Realistic laboratory simulations stand out as an important and innovative strategy that can be used to give healthcare professionals the opportunity to visualize their strengths and difficulties during the delivery of care. This type of training enables professionals to review their care practices, updating their knowledge about microorganism transmission, and precautions and isolation measures. When it comes to emergency rooms (overcrowding, unpredictability and complexity), this strategy is fundamental, since it contributes to the improvement of skills and development of safer attitudes.

A limitation of the present study is that the data collection was performed by only one observer, which reduced the number of observations. However, as a bonus, it is believed that this decreased the possibility of collector bias during observation. Another issue is that the indiscriminate use of gloves in procedures made it difficult to evaluate the indications for hand hygiene. Additionally, the Hawthorne effect, although not statistically proven, was observed in the results regarding hand hygiene compliance in monitoring sessions $1(50.8 \%)$ and $3(59.6 \%)$. The possibility of changing behaviors and attitudes related to observation cannot be ruled out. Moreover, a lack of national and international studies that used emergency rooms as the study scenario in the databases surveyed limited the discussion and comparison of the results found. Another factor was the use of different instruments for assessing compliance.

\section{CONCLUSION}

The hand hygiene compliance rate in an adult emergency room was low (54.2\%). To promote an environment with a safety culture, it is necessary that both health professionals and managers incorporate safe practices related to hand hygiene. An adequate infrastructure and multidisciplinary educational approaches are appropriate. Thus, bringing hospital infection control services and patient safety centers closer to health professionals could be an important strategy for forming partnerships to develop the learning and implementation of hand hygiene practices.

In emergency rooms, as in ICUs, it is suggested that placing alcohol preparations at the bedside favors hand hygiene in the WHO five moments during patient care.

It is believed that the results of the present study will serve as encouragement for safe care practices in this and other scenarios that are similar to the one described. In addition, improvement actions could be planned with multiprofessional teams, in order to have a positive impact on hand hygiene compliance rates.

\section{RESUMO}

Objetivo: Analisar a adesão à higienização das mãos dos profissionais de saúde em unidade de Pronto-Socorro. Método: Estudo quantitativo longitudinal desenvolvido com profissionais de saúde de um Hospital Universitário do Rio Grande do Sul, em 2015. Para cada profissional, realizaram-se três acompanhamentos com observação direta não participante nos cinco momentos preconizados para higienização das mãos, levando-se em conta os conceitos de Oportunidade, Indicação e Ação. Utilizou-se da estatística descritiva e analítica. Resultados: Participaram do estudo 59 profissionais de saúde. A taxa de adesão foi de 54,2\%. Os enfermeiros e fisioterapeutas obtiveram a taxa de adesão de $66,6 \%$ e os médicos residentes, de $41,3 \%$. Ao ser comparada a adesão entre as categorias profissionais, os enfermeiros tiveram maior aderência do que os médicos residentes $(\mathrm{RC}=2,83 ; \mathrm{IC}=95 \%: 1,09-7,34)$. Conclusão: $\mathrm{A}$ adesão à higienização das mãos foi baixa. Abordagens multidisciplinares podem ser estratégias importantes para formar parcerias que desenvolvam a aprendizagem e a efetivação de práticas de HM.

\section{DESCRITORES}

Higiene das Mãos; Segurança do Paciente; Infecção Hospitalar; Enfermagem em Emergência; Adesão a Diretivas Antecipadas; Serviços Médicos de Emergência.

\section{RESUMEN}

Objetivo: Analizar la adhesión de los profesionales sanitarios a la higienización de las manos en servicio de urgencias. Método: Estudio 
cuantitativo longitudinal desarrollado con profesionales sanitarios de un Hospital Universitario de Río Grande do Sul, en 2015. Para cada profesional, se llevaron a cabo tres acompañamientos con observación directa no participante en los cinco momentos preconizados para la higienización de las manos, teniendo en cuenta los conceptos de Oportunidad, Indicación y Acción. Se utilizó la estadística descriptiva y analítica. Resultados: Participaron en el estudio 59 profesionales sanitarios. La tasa de adhesión fue del 54,2\%. Los enfermeros y fisioterapeutas obtuvieron la tasa de adhesión del 66,6\% y los médicos residentes, del 41,3\%. Al compararse la adhesión entre las categorías profesionales, los enfermeros tuvieron mayor adherencia que los médicos residentes $(\mathrm{RC}=2,83 ; \mathrm{IC}=95 \%: 1,09-7,34)$. Conclusión: La adhesión a la higienización de las manos fue baja. Abordajes multidisciplinarios pueden ser estrategias importantes para formar alianzas que desarrollen el aprendizaje y la puesta en marcha de prácticas de HM.

\section{DESCRIPTORES}

Higiene de las Manos; Seguridad del Paciente; Infección Hospitalaria; Enfermería de Urgencia; Adhesión a las Directivas Anticipadas; Servicios Médicos de Urgencia.

\section{REFERENCES}

1. Carter EJ, Pouch SM, Larson E. Common infection control practices in the Emergency Department: a literature review. Am J Infect Control. 2014;42(9):957-62.

2. World Health Organization. WHO Guidelines on Hand Hygiene in Health Care (Advanced Draft): a summary. Clean hands are safer hands [Internet]. Geneva: WHO; 2005 [cited 2014 June 10]. Available from: http://www.who.int/patientsafety/events/05/HH_en.pdf

3. Santos TCR, Roseira CE, Piai-Morais TH, Figueiredo RM. Higienização das mãos em ambiente hospitalar: uso de indicadores de conformidade. Rev Gaúcha Enferm [Internet]. 2014 [citado 2014 jun. 03];35(1):70-7. Available from: http://seer.ufrgs.br/index.php/ RevistaGauchadeEnfermagem/article/view/40930/28935

4. Pittet D, Hugonnet S, Harbarth S, Mourouga P, Sauvan V, Touveneau S, et al. Effectiveness of a hospital-wide programme to improve compliance with hand hygiene. Lancet. 2000;356(9238):1307-12.

5. Allegranzi B, Sax H, Bengaly L, Richet H, Minta DK, Chraiti MN, et al. Successful Implementation of the World Health Organization Hand Hygiene improvement strategy in a referral hospital in Mali, Africa. Infect Control Hosp Epidemiol. 2010;31(2):133-41.

6. Boyce JM, Pittet D. Guideline for Hand Hygiene in Health-Care Settings: recommendations of the Healthcare Infection Control Practices Advisory Committee and the HICPAC/SHEA/APIC/IDSA Hand Hygiene Task Force. MMWR Recomm Rep. 2002;51(RR-16):1-45.

7. Qushmaq IA, Heels-Ansdell D, Cook DJ, Loeb MB, Meade MO. Hand hygiene in the intensive care unit: prospective observations of clinical practice. Pol Arch Med Wewn. 2008;118(10):543-47.

8. Riveros Pérez E, Zambrano P, Amado P. Adherencia a las guías de higiene de manos en cuidado intensivo: el caso de una clínica privada. Med UPB [Internet]. 2012 [citado 2014 jun. 10]; 31(2):127-34. Disponíble en: https://revistas.upb.edu.co/index.php/Medicina/article/ view/1760/pdf

9. Muller MP, Carter E, Siddiqui N, Larson E. Hand hygiene compliance in an Emergency Department: the effect on crowding. Acad Emerg Med. 2015;22(10):1218-21.

10. Block L, Habicht R, Oluyadi FO, Wu AW, Desai SV, Niessen T, et al. Variability in hand hygiene practices among internal medicine interns. Am J Infect Control. 2013;41(11):1107-8.

11. Sax H, Allegranzi B, Uçkay I, Larson E, Boyce J, Pittet D. 'My five moments for hand hygiene': a user-centred design approach to understand, train, monitor and report hand hygiene. J Hosp Infect. 2007;67(1):9-21.

12. Organização Pan-Americana da Saúde; Agência Nacional de Vigilância Sanitária. Manual para observadores: estratégia multimodal da OMS para a melhoria da higienização das mãos. Brasília: OPAS/ANVISA; 2008.

13. The Joint Commission. Measuring hand hygiene adherence: overcoming the challenges: hand hygiene [Internet]. Oakbrook Terrace, Illinois; 2009 [cited 2014 Sept 08]. Available from: https://www.jointcommission.org/assets/1/18/hh_monograph.pdf

14. Steed C, Kelly JW, Blackhurst D, Boeker S, Diller T, Alper P, et al. Hospital hand hygiene opportunities: where and when (HOW2)? The HOW2 Benchmark Study. Am J Infect Control. 2011;39(1):19-26.

15. Prado MF, Oliveira ACJ, Nascimento TMB, Melo WA, Prado DB. Estratégia de promoção à higienização das mãos em unidade de terapia intensiva. Ciênc Cuid Saúde [Internet]. 2012. [citado 2014 jun. 10]; 11(3):557-64. Available from: http://periodicos.uem.br/ojs/index. php/\%20CiencCuidSaude/\%20article/view/16366

16. Souza LM, Ramos MF, Becker ESS, Meirelles LCS, Monteiro SAO. Adesão dos profissionais de terapia intensiva aos cinco momentos da higienização das mãos. Rev Gaúcha Enferm [Internet]. 2015 [citado 2016 jan. 31];36(4):21-8. Available from: http://www.seer.ufrgs.br/ index.php/RevistaGauchadeEnfermagem/article/view/49090

17. Oliveira AC, Cardoso CS, Mascarenhas D. Contact precautions in Intensive Care Units: facilitating and inhibiting factors for professionals' adherence. Rev Esc Enferm USP [Internet]. 2010 [cited 2015 Jan 10]; 44(1):159-63. Available from: http://www.scielo.br/pdf/reeusp/v44n1/ en_a23v44n1.pdf

18. Brasil. Ministério da Saúde; Agência Nacional de Vigilância Sanitária. RDC nº 42, de 25 de outubro de 2010. Dispõe sobre a obrigatoriedade de disponibilização de preparação alcoólica para fricção antisséptica das mãos, pelos serviços de saúde do país e dá outras providências [Internet]. Brasília: ANVISA; 2010 [citado 16 jan. 2016]. Available from: http://bvsms.saude.gov.br/bvs/saudelegis/ anvisa/2010/res0042_25_10_2010.html

19. Prado MF, Maran E. The challenge in the use of alcoholic preparations for hand hygiene in healthcare services. Esc Anna Nery [Internet]. 2014 [cited 2015 Dec 08];18(3):544-7. Available from: http://www.scielo.br/pdf/ean/v18n3/en_1414-8145-ean-18-03-0544.pdf 
20. Ezaias GM, Watanabe E, Shimura CMN. Skin tolerance to alcohol-based preparations: basis for improvement of hand hygiene practices. J Nurs UFPE on line [Internet]. 2016. [citado 2016 set 16]; 34(2): 10(8):2923-32. Available from: http://www.revista.ufpe.br/ revistaenfermagem/index.php/revista/article/view/9437/pdf_10790

21. Hass JP, Larson LE. Impact of wearable alcohol gel dispensers on hand hygiene in an Emergency Department. Acad Emerg Med. 2008;15(4)393-6.

22. Bathke J, Cunico PA, Maziero ECS, Cauduro FLF, Sarquis LMM, Cruz EDA. Infraestrutura e adesão à higienização das mãos: desafios à segurança do paciente. Rev Gaúcha Enferm [Internet]. 2013 [citado 2016 jan. 16];34(2):78-85. Available from: http://www.scielo.br/pdf/ rgenf/v34n2/v34n2a10.pdf

23. Salmon S, Tran HL, Bùi DP, Pittet D, McLaws ML. Beginning the journey of hand hygiene compliance monitoring at a 2,100-bed tertiary hospital in Vietnam. Am J Infect Control. 2014;42(1):71-3.

24. Costa LSS, Neves VM, Marra AR, Camargo TZS, Cardoso MFS, Victor ES, et al. Measuring hand hygiene compliance in a hematologyoncology unit: A comparative study of methodologies. Am J Infect Control. 2013;41(11):997-1000.

25. Herrera-Usagre M, Pérez-Pérez P, Vázquez-Vázquez M, Santana-López V. Profesionales de salud ante la mejora de la higiene de las manos: estrategias clásicas versus estrategias avanzadas. Rev Chil Infectol [Internet]. 2014 [citado 2016 jan. 21];31(5):534-41. Disponible en: http://www.scielo.cl/scielo.php?pid=S0716-10182014000500004\&script=sci_arttext

26. Salmon S, Pittetb D, Saxc H, McLaws ML. The 'My five moments for hand hygiene' concept for the overcrowded setting in resource-limited healthcare systems. J Hosp Infect. 2015;91(2):95-9.

27. Nair SS, Hanumantappa R, Hiremath SG, Siraj MA, Raghunath P. Knowledge, attitude, and practice of hand hygiene among medical and nursing students at a Tertiary Health Care Centre in Raichur, India. ISRN Prev Med. 2014;2014:608927.

Financial support:

Program of Scientific Initiation Grant PIBIC/CNPq/UFSM. Edital 2015-2016. 